\title{
Telehealth as a medical education tool during the COVID-19 pandemic: experience report
}

\section{Telessaúde como ferramenta na formação médica durante a pandemia da COVID-19: relato de experiência}

\author{
Matheus Augusto Obici Massucato' (D) matheus.massucato@ufms.br \\ Ana Luísa Green Ribeiro' (1) algr952@gmail.com \\ Juliana Dias Reis Pessalacia' (D) juliana@pessalacia.com.br \\ Vinicius de Jesus Rodrigues Neves ${ }^{1}$ (D) viniciusjr.mfc@gmail.com \\ Vânia Paula Stolte-Rodrigues² (D) vania.stolte@gmail.com
}

\begin{abstract}
Introduction: The Covid-19 pandemic interrupted and challenged the traditional structure of medical education, based on face-to-face teaching, and, as a measure of support for the efforts of government agencies to reduce the risk of spreading the disease, distance became necessary. medical/patient care and the increase in the supply of telehealth services by health systems. In Brazil, the telehealth model seeks to improve the quality of care in primary health care (PHC), integrating education and service through tele-education and tele-assistance activities, such as teleconsulting, the Second Formative Opinion (SOF), tele-education and telediagnosis. Thus, this article reports the experience of medical students in telehealth actions during the Covid-19 pandemic in Brazil, seeking to clarify the contributions and limitations of this experience in the teaching-learning process in the context of medical education.

Experience report: Participation in the project allowed the experience of various telehealth activities under the supervision and guidance of professors in the health area, in addition to the production of informative and educational materials. The proposed activities allowed for the improvement of clinical reasoning through evidence-based medicine (EBM), especially in helping teleconsultations and frequently asked questions.

Discussion: The use of technologies became indispensable during the pandemic, and, within this scenario, a telehealth project proved to be an important and effective strategy for continuing education among professionals and health education for the community, avoiding crowding and preventing the spread of the virus. In addition, remote actions, such as teleconsultations, resolution of frequently asked questions and teleeducation, proved to be an important strategy for accessing health care not only in times of pandemic.

Conclusion: Our experience made it possible to foster critical thinking and disseminate content in a safe, technical and evidence-based way. The exercise of clinical reasoning led us to an experience of great value and to believe that the inclusion of the practice of telehealth can bring important gains to the curriculum of Medicine courses.
\end{abstract}

Keywords: Telemedicine; Students; Medical Education; Medical School; Coronavirus Infections.

\section{RESUMO}

Introdução: A pandemia da Covid-19 interrompeu e desafiou a estrutura tradicional da educação médica, fundamentada no ensino presencial, e, como medida de apoio aos esforços dos órgãos governamentais para a redução dos riscos de disseminação da doença, tornaram-se necessários o distanciamento do atendimento médico/paciente e o aumento da oferta de serviços de telessaúde pelos sistemas de saúde. No Brasil, o modelo de telessaúde busca melhorar a qualidade do atendimento da atenção primária à saúde (APS), integrando ensino e serviço por meio de atividades de teleducação e teleassistência, tais como a teleconsultoria, a Segunda Opinião Formativa (SOF), a teleducação e o telediagnóstico. Assim, este artigo relata a experiência de estudantes de Medicina em ações de telessaúde durante a pandemia da Covid-19 no Brasil, buscando esclarecer as contribuições e limitações dessa experiência no processo ensino-aprendizado no contexto da formação médica.

Relato de experiência: A participação no projeto permitiu a vivência de diversas atividades de telessaúde sob a supervisão e orientação de docentes da área de saúde, além da produção de materiais informativos e educativos. As atividades propostas permitiram o aprimoramento do raciocínio clínico por meio da medicina baseada em evidências (MBE), principalmente no auxílio a teleconsultorias e perguntas frequentes.

Discussão: $O$ uso de tecnologias tornou-se indispensável durante a pandemia, e, dentro desse cenário, um projeto de telessaúde mostrou-se como uma estratégia importante e eficaz para educação permanente entre profissionais e educação em saúde para a comunidade, evitando aglomerações e prevenindo a disseminação do vírus. Além disso, as ações de forma remota, como teleconsultorias, resoluções de perguntas frequentes e teleducação, mostraram ser uma estratégia importante de acesso à saúde não somente em tempos de pandemia.

Conclusão: Nossa experiência possibilitou fomentar o senso crítico e disseminar conteúdo de forma segura, técnica e baseada em evidências. O exercício do raciocínio clínico nos levou a uma experiência de grande valia e a crer que a inclusão da prática de telessaúde pode trazer ganhos importantes à grade curricular dos cursos de Medicina.

Palavras-chave: Telemedicina; Estudantes; Educação de Graduação em Medicina; Faculdades de Medicina; Infecções por Coronavírus.

${ }^{1}$ Universidade Federal de Mato Grosso do Sul, Três Lagoas, Mato Grosso do Sul, Brazil.

2 State Health Secretariat of Mato Grosso do Sul, Três Lagoas, Mato Grosso do Sul, Brazil. 


\section{INTRODUCTION}

The World Health Organization (WHO) and the American Telemedicine Association define telemedicine as the use of electronic communication and information technologies to provide remote clinical services ${ }^{1}$. Telehealth as a project includes a broader scope of remote assistance services, such as training providers, administrative meetings and continuing education, in addition to contemplating Telemedicine clinical services ${ }^{2}$.

The current context of the Corona Virus Disease (COVID-19) pandemic has created unprecedented stress for managers and professionals in the health and education systems, generating practical and logistical challenges for the learning environment that can have a lasting impact on medical education ${ }^{3-5}$.

The new pandemic interrupted and challenged the traditional and well-established structure of undergraduate and graduate medical education - whose training is based on face-to-face teaching ${ }^{4}$. As a measure of support to the efforts of government agencies to reduce the risk of spreading the disease, it became necessary to implement distancing in medical/patient care during the pandemic and to increase the offer of Telehealth services by health systems ${ }^{3}$.

The Federal Council of Medicine (CFM, Conselho Federal de Medicina) through letter N. 1.756/2020 sent to the Ministry of Health and Ordinance N. 476, of March 20, 2020, sought the improvement and efficiency of medical services provided under special circumstances and while actions to combat COVID-19 in Brazil last, through the ethical practice of using telemedicine for teleorientation, telemonitoring and teleconsultation, based on the need to protect both the health of physicians and patients ${ }^{6}$.

However, in other countries, such as Australia ${ }^{7}$ and France $^{8}$, Telehealth services are already regulated and receive investments in technologies and government incentives. In these countries, actions aimed at the education and training of professionals and the integration of the subject in medical curricula have also been supported.

In Brazil, the Telehealth model seeks to improve the quality of care in Primary Health Care (PHC), integrating teaching and service through tele-education and teleassistance activities, mainly aimed at strengthening the Family Health Strategy $(E S F)^{9}$. Telehealth involves different approaches, such as teleconsulting, the Second Formative Opinion (SFO), tele-education and telediagnosis ${ }^{10}$.

In this scenario of advances in Telehealth actions, it is necessary to train students in the use of digital tools, and education on their limitations should be part of undergraduate education. Medical graduation curricula should also be reviewed aiming to prepare future physicians for a dominant era of telemedicine ${ }^{11}$. In the North American context, for instance, medical students are involved in telehealth actions as part of their clinical rotations, although the experience of the studentconsultant and the general benefits for their training are still scarcely described in the literature ${ }^{12}$. Therefore, as medical schools adapt to this new medical education component, the students' transition to telemedicine should be prioritized, since it will have an important role in the future ${ }^{11}$.

The practice of Telehealth remains scarcely covered in medical education curricula in Brazil and there is limited literature on the experience of medical students in this modality of care, this article seeks to report the experience of medical students in Telehealth actions during the COVID-19 pandemic in Brazil, for the purpose of clarify the contributions and limitations of this experience in the teaching-learning process in the context of medical training.

\section{EXPERIENCE REPORT}

The medical students' approach to Telehealth actions started with their participation in an extension project approved in an Extraordinary Public Notice of Universidade Federal de Mato Grosso do Sul (UFMS) (COVID-19 - PROJECTS AND IDEAS - PROPP/PROECE/AGINOVA /UFMS 22/2020) aimed at proposing projects, ideas and actions to face the challenges experienced by society as a result of the pandemic.

Therefore, the proposal of a Telehealth project at the Três Lagoas campus (CPTL/UFMS) emerged from the perception of medical school teachers about the need to work in the current global context of advances in the field of Information and Communication Technologies (ICTs), which have provided the reach of teleeducation and telemedicine actions by means of social networks, web-based applications, teleconsultations, teleconferences and multimedia approaches (digital images and video).

Between May and December 2020 (period affected by the pandemic), the unit developed actions of asynchronous teleconsulting, tele-education and SFO, with the activities being developed with the participation of ten medical students (from different periods) and 18 teachers of the courses of Medicine and Nursing.

For the extension project of the Telehealth CPTL Unit, the following objectives were proposed: to create educational videos and digital materials about COVID-19 and make them available to the entire population of the state, through social networks, the websites of partner institutions and WhatsApp; the training of teachers and students from the team to carry out teleconsultation and tele-education actions; the resolution of teleconsultations sent by $\mathrm{PHC}$ health professionals across the state and; the publication of frequently asked questions about COVID-19 on the page of the Telehealth Center of the State of Mato Grosso do Sul/Brazil. We worked under the General Coordination of a teacher, who was 
responsible for planning actions at unit (CPTL) and in charge of mediation with the State Telehealth Center.

Therefore, during the initial period of the unit activities, the following were produced:

- Twelve short videos that were published on the project's Instagram (https://www.instagram.com/ tlsaudeufms/), on the state's Telehealth Center page on Facebook (https://www.facebook.com/ tlsaudeufms/) and on the Telessaúde MS website (http://www.telessaude.saude.ms.gov.br/).

- $\quad$ Sixty-eight teleconsultations carried out by health professionals from the APS in the state of Mato Grosso do Sul.

- Seventeen questions a week, which are posted on the state's Telehealth Center website, accessible to all health professionals and the general population.

- Two SOFs in the areas of pharmacology and gynecology and obstetrics, which are published on the page of the Virtual Health Library (VHL) and the state's Telehealth Center.

The task of meeting the community's needs and clarifying doubts started with the proposal to create and disseminate short videos that were mainly aimed at the context of the COVID-19 pandemic experienced throughout Brazil. Subsequently, the topics proposed for the videos were divided by pairs who should publish their videos weekly on the project's social networks and together with professionals from the Basic Health Units (BHUs) in the municipality of Três Lagoas/MS.

The addressed topics were chosen in common agreement between the coordinators of the Mato Grosso do Sul Telehealth Center of the State Health Secretariat/MS (SES), the Municipal Health Secretariat (SMS) of Três Lagoas and the CPTL/UFMS Telehealth Unit, including topics related to mental health during social isolation; forms of transmission of the coronavirus; domestic violence in the pandemic; clinical care for risk groups; use of PPEs; home isolation, among others.

The assembling and editing of the videos were carried out by the CPTL/UFMS Telehealth Unit, following scripts previously submitted for approval by the Três Lagoas SMS team and the Telehealth SES/MS team, before the final edition of the material. Nevertheless, the Telehealth Center was responsible for promoting their distribution through its official channel, which was corroborated by sharing them in our unit's social networks.

During the short video production process, as the project does not have funding aimed at contracting more robust digital tools, the unit used free and accessible tools, which, however, did not compromise the quality of the material. The lack of an adequate recording environment corroborated the lack of standardization of recording environments, styles, sound and image quality. However, even when carried out using non-standard tools, we considered it a successful mission, of offering quality content to the entire community, with scientific information, but using language that was accessible to the target population, one of the purposes of our project.

Thus, the production of short videos in the project allowed us greater knowledge about the types and specificities of available digital tools and how to handle them. In this sense, we can highlight that the experience was of great relevance to our training, given the need for professionals with skills in evidencebased health communication in social networks to promote adequate orientation at an atypical and uncertain moment.

Regarding the teleconsultations, they were carried out asynchronously, due to difficulties in synchronizing the schedules of the applicant and the teleconsultant teachers. The teleconsultations were initiated by PHC professionals, sent to teleconsultants accredited by the Telehealth Center, who discussed the issues presented in the clinical study format with us and, finally, the response to the questions was sent within 72 hours.

Dealing with real cases, seeking to help requesting professionals during the stages of diagnosis, treatment/ therapeutics, use and prescription of medications, among other care actions, allowed us to improve research activities, manage information in a democratic way and integrate the theoretical knowledge learned during undergraduate school to practical resolutions in helping different professionals of the health team - Community Health Agents (CHA), nurses, doctors, nutritionists, psychologists, among others.

Our participation in the creation of the response to teleconsultations allowed us to improve clinical reasoning skills and knowledge of the main reasons for referring $\mathrm{PHC}$ users to specialized services. We also realized that most of the PHC professionals' doubts could be handled by the unit team with the help of telehealth, without the need for referrals to specialized care, making the $\mathrm{PHC}$ service more effective and reducing waiting lines.

The 'questions of the week' were sent by the Telehealth Center based on the survey of the most frequently asked questions in teleconsultations. A dissemination strategy used in our CPTL/UFMS telehealth unit, in addition to official posts on the Telehealth MS website in the 'Questions of the Week' tab, was making a Chat Room available to clarify doubts on social networks, especially Instagram and Facebook - with posts, stories and quizzes about the covered topic. From this tool, other medical students and people from the community could direct their doubts to the team at the CPTL/UFMS Telehealth Unit.

We also participated in the creation of a Second Formative Opinion published on the OPAS/PAHO Virtual Health 
Library website, in the area of Gynecology and Obstetrics. This is a necessary tool for the dissemination of topics of utmost relevance in the scientific community that may solve future medical appointments, either in-person or remote ones.

Finally, we verified that the use of social networks for the sharing of information and interaction allowed us to experience and realize the importance of this communication and learning space for our training. However, as a negative point, we observed a low population adherence to this resource, perhaps due to internet access problems. Even though we reached 413 followers on Instagram a month after the creation of the page and 431 followers in March 2021, we still felt that there was a certain restriction regarding people's engagement to our publications. On Facebook, the "Telessaúde UFMS Três Lagoas" page attracted 524 likes, that is, 524 people directly followed the post published on this social network; however, anyone with an account would be able to view the content we published.

\section{DISCUSSION}

The experience allowed the improvement of theoretical and practical knowledge about tools for the development of digital educational materials. This knowledge becomes extremely relevant given the advance of ICTs, which constitute an important means of accessing health information. The growing importance of ICTs in the area of Health Education allows the development of creative, innovative and bold pedagogical health initiatives, which strengthen the interface between communication, science and society ${ }^{13}$.

Nevertheless, it is important to highlight the relevance of offering content with broad scientific support and a high level of scientific evidence. For that purpose, the recommendations described in the Protocol of Responses to Teleconsultations of the Ministry of Health ${ }^{10}$ and publications in scientific journals available in national and international databases were considered. This fact showed to be absolutely necessary, especially during the epidemic scenario, since COVID-19 is an unprecedented disease of which the majority of the population still does not understand the cause and effect, a perfect scenario for the circulation of false information, often not verified and that causes doubts to the population. Thus, aiming to fight the practice of 'fake news', it is important to create spaces for communication and clarification of doubts in the Telehealth Centers with questions and answers, in order to avoid false news about COVID-1914.

The process of creating the videos and educational materials made it possible the theoretical improvement of the topics based on research in scientific databases, allowing the identification of the databases and the best scientific evidence. Knowledge about Evidence-Based Medicine (EBM) and about research in databases is extremely relevant for the student's role in the learning process, which has implications for the excellence of future professionals. A study carried out with medical students at a university in the state of Pernambuco, Brazil, found that more than $50 \%$ of the students (68.3\%) still consider research in physical books and most have not received training in EBM or in bibliographic research techniques in specialized databases ${ }^{15}$.

Moreover, the objective was to join the scientific and lay communities, aiming to strengthen the ties between society and the university and ensure a social return of the activities performed by the public university. In this context, it was purposed that the content - be it of a technical or everyday nature - is approached in a simplified way through the use of simple language, without pedantism and easy to understand ${ }^{6}$.

The sharing of information through social networks aimed to achieve the greatest possible engagement and respect measures of social distancing in the epidemiological scenario. About this fact, a study carried out with 310 medical students aimed to assess the contributions of social networks (main platform for the dissemination of the Center activities) in teaching undergraduate medical students, identified the sharing of information, the interaction between people, easy and fast activities, and the creation of groups as advantages ${ }^{16}$.

In particular, the development of experiences in the project allowed the discussion of content provided for in the medical course curriculum using a teleconsulting format, favoring the medical student training and, therefore, the need to include the teaching of telemedicine in the curricula of undergraduate courses is emphasized ${ }^{11}$.

In addition to preventing many patients from exposing themselves to possible contamination by the virus when seeking a health service in a scenario of wide spread of infectious and contagious diseases, it is worth reinforcing the social role of teleconsultations, which provide care to patients who live far from health care facilities, allowing them to avoid long journeys and higher costs ${ }^{17}$.

However, it is extremely valid to highlight the importance of meeting the requirement of permanent education in teleconsultations. It fulfilled the objective of promoting health education by leading the requesting professional to carry out future research in databases, promoting continuing medical education ${ }^{2,18}$. Furthermore, it was observed that this fact had direct effects during the course of the project, with an impact on the actions that should have been taken by that professional before the request, in addition to frequently orienting the request and correct filling out of teleconsultations -- when requested with insufficient information or in the absence of some relevant information that could be mentioned - and 
to promote a holistic treatment, as well as the practice of Preventive Medicine for the patient.

The production of SFO ends up strengthening the connections with $\mathrm{PHC}$ and the population in general (they were published on the Telessaúde MS website with wide and free access), because they are based on the best scientific and clinical evidence and contribute to the regulating role of this level of attention and to solve frequent doubts that are addressed to health professionals who participated directly or indirectly in the project ${ }^{19}$.

Finally, it is worth mentioning that the lack of engagement by the population identified in this experience, which was also reported in another Brazilian study ${ }^{20}$, and the approach taken by students, and not by trained professionals, was identified as an impediment to greater adherence.

Although the use of Telehealth is still low in Brazil, there has been a large increase in the use of these services during the COVID-19 pandemic, through the authorization and encouragement of the teleconsultation use, which was not yet regulated in the country. It is believed that the successful use of Telehealth in this period will contribute to its greater public and governmental acceptance in the country and to greater investments in training professionals in the use of these technologies ${ }^{14}$.

\section{FINAL CONSIDERATIONS}

Based on what was exposed in this article, it is concluded that the participation of medical students in Telehealth activities resulted in a very positive balance in the professional and personal training of those involved. The participation of students in actions aimed at minimizing the population's exposure to the virus and greater effectiveness of $\mathrm{PHC}$ services during the pandemic, thereby reducing the anxiety of students who are unable to attend in-person classes during this period.

One of the purposes of Telehealth was to establish experiences between students and health professionals in the performance of skills that must be carried out and are required for good medical education, in addition to allowing the creation of a reliable and scientific communication channel with the community in general. Therefore, a means of transmitting information for the practice of Evidence-Based Medicine was established, in addition to improving the critical sense of both students and those requesting the teleconsultations.

Furthermore, the improvement of students' knowledge about ICTs was encouraged, which will certainly be part of their future professional daily life. Considering all this, it is necessary to include theoretical and practical contents in Telehealth in the curricula of medical courses, aiming to provide students with knowledge about this type of service and promote experiences such as the ones reported herein.

\section{AUTHORS' CONTRIBUTION}

Matheus Augusto Obici Massucato: manuscript writing and editing; final review. Ana Luísa Green Ribeiro: manuscript writing and editing. Juliana Dias Reis Pessalacia: manuscript editing and review; orientation. Vinicius de Jesus Rodrigues Neves: manuscript editing and review; orientation. Vânia Paula Stolte-Rodrigues: manuscript editing and review.

\section{CONFLICTS OF INTEREST}

The authors declare no conflicts of interest.

\section{SOURCES OF FUNDING}

The authors declare no sources of funding.

\section{REFERENCES}

1. Shirke MM, Shaikh SA, Harky A. Implications of telemedicine in oncology during the Covid-19 pandemic. Acta Biomed. 2020 Sept 7;91(3):e2020022 doi: 10.23750/abm.v91i3.9849.

2. Pollock K, Setzen M, Svider PF. Embracing telemedicine into your otolaryngology practice amid the Covid-19 crisis: an invited commentary. Am J Otolaryngol. 2020;41(3):e102490. doi: 10.1016/j.amjoto.2020.102629.

3. Lancu AM, Kemp MT, Alam HB. Unmuting medical students' education: utilizing telemedicine during the Covid-19 pandemic and beyond. J Med Internet Res. 2020 July 20;22(7):e19667. doi: 10.2196/19667.

4. Hilburg R, Patel N, Ambruso S, Biewald MA, Farouk SS. Medical education during the coronavirus disease-2019 pandemic: learning from a distance. Adv Chronic Kidney Dis. 2020;27(5):412-7. doi: 10.1053/j.ackd.2020.05.017.

5. Pitt MB, LiST, Klein M. Novel educational responses to Covid-19: what is here to stay? Acad Pediatr. 2020;20(6):733-4. doi: 10.1016/j.acap.2020.06.002.

6. Brasil. Portaria n 467, de 20 março de 20. Dispõe, em caráter excepcional e temporário, sobre as ações de Telemedicina, com o objetivo de regulamentar e operacionalizar as medidas de enfrentamento da emergência de saúde pública de importância internacional previstas no art. $3^{\circ}$ da Lei no 13.979, de 6 de fevereiro de 2020, decorrente da epidemia de Covid-19 [acesso em 14 abr 2021]. Disponível em: https://bvsms.saude. gov.br/bvs/saudelegis/gm/2020/prt0467_23_03_2020_extra.html.

7. Rienits $\mathrm{H}$, Teuss $\mathrm{G}$, Bonney $\mathrm{A}$. Teaching telehealth consultation skills. Clinic Teach 2015;13(2):119-23. doi: 10.1111/tct.12378.

8. Yaghobian S, Ohannessian R, lampetro T, Riom I, Salles N, de Bustos EM, et al. Knowledge, attitudes and practices of telemedicine education and training of French medical students and residents. J Telemed Telecare. 2020 June 9;0(0):1-9. doi: 10.1177/1357633X20926829.

9. Damasceno RF, Caldeira AP. Fatores associados à não utilização da teleconsultoria por médicos da Estratégia Saúde da Família. Ciênc. Saúde Colet. 2019;24(8):3089-98. doi: 10.1590/1413-81232018248.28752017.

10. Ministério da Saúde, Universidade Federal do Rio Grande do Sul. Manual de telessaúde para a atenção básica/atenção primária à saúde: protocolo de solicitação de teleconsultorias. Porto Alegre: Universidade Federal do Rio Grande do Sul; Brasília: Ministério da Saúde; 2013

11. Rallis KS, Allen-Tejerina AM. Tele-oncology in the Covid-19 era: are medical students left behind? Trends Cancer. 2020 Oct;6(10):811-2. doi: 10.1016/j. trecan.2020.08.001

12. Kopp AR, Rikin S, Cassese T, Berger MA, Raff AC, Gendlina I. Medical student remote eConsult participation during the Covid-19 pandemic. BMC Med Educ. 2021 Feb 22;21:e120. doi: 10.1186/s12909-021-02562-6.

13. França T, Rabello ET, Magnago C. As mídias e as plataformas digitais no campo da educação permanente em saúde: debates e propostas. Saúde Debate. 2019;43(esp 1):106-15. doi: 1590/0103-11042019s109. 
14. Caetano R, Silva AB, Guedes AC, Paiva CC, Ribeiro GR, Santos DL, et al. Desafios e oportunidades para telessaúde em tempos da pandemia pela Covid-19: uma reflexão sobre os espaços e iniciativas no contexto brasileiro. Cad Saude Publica. 2020;36(5):e00088920. doi: 10.1590/0102$311 \times 00088920$.

15. Lorena SB, Andrade MM, Arcoverde AH, Vilela LS, Mota LA, Lorena Sobrinho JE. Análise do acesso à informação acadêmica entre estudantes de Medicina inseridos numa metodologia ativa de aprendizagem. Rev Bras Educ Med. 2019;43(4):176-86. doi: 10.1590/1981-52712015v43n4rb20190037.

16. Purim KM, Tizzot EA. Protagonismo dos estudantes de Medicina no uso do Facebook na graduação. Rev Bras Educ Med. 2019;43(1):187-96. doi: 10.1590/1981-52712015v43n1rb20180139.

17. Lee MS, Nambudiri V. Integrating telemedicine into training: adding value to graduate medical education through electronic consultations. J Grad Med Educ. 2019;11(3):251-4. doi: 10.4300/JGME-D-18-00754.1.
18. Maeyama MA, Calvo MC. A integração do telessaúde nas centrais de regulação: a teleconsultoria como mediadora entre a atenção básica e a atenção especializada. Rev Bras Educ Med. 2018;42(2):63-72. doi: 10.1590/1981-52712015v42n2rb20170125.

19. Guimarães EM, Godoy SC, Silva LF, Trindade, RM. A Segunda Opinião Formativa como instrumento de educação permanente na telenfermagem. J Bras Telessaúde. 2018;5(1):247-8.

20. Dimer NA, Canto-Soares ND, Santos-Teixeira LD, Goulart BNG. The Covid-19 pandemic and the implementation of telehealth in speech-language and hearing therapy for patients at home: an experience report. Codas. 2020 June 22;32(3):e20200144. doi: 10.1590/2317-1782/20192020144. 